\title{
Pola nafkah petani kopi: kajian petani kopi di desa tertinggal di Kabupaten Jeneponto
}

\author{
Cofee farmer ilvelihood patterns: study of cofee farmers in disadvantaged villages in \\ Jeneponto Regency
}

\author{
Isnam Junais
}

Fakultas Pertanian, Universitas Muhammadiyah Makassar

Corresponding author: Iznamjz@gmail.com

Diterima tanggal 09 Agustus 2019, Disetujui tanggal 30 Agustus 2019

\begin{abstract}
Abstrak
Kemiskinan sangat identik dengan masyarakat petani, jeratan kemiskinan seolah menjadi penyakit masyarakat yang sudah turun temurun. Salah satu faktor yang memperparah kondisi ini adalah kurangnya sumber daya masyarakat petani dalam mengelola potensi yang dimiliki.Penelitian ini bertujuan untuk melihat pola nafkah petani kopi di sebuah desa tertinggal. Penelitian ini melibatkan 70 keluarga petani yang diwawancarai. Analisis data menggunakan pendekatan data kuantitatif yang kemudian didukung dengan pendekatan kualitatif. Hasil penelitian menunjukkan bahwa, ketidakmampuan petani dalam memenuhi kebutuhannya sepenuhnya bukan karena kurangnya pendapatan petani namun, ketidakmampuan petani dalam mengelola keuangan dalam rangka memenuhi kebutuhan keluarga. Pendapatan petani yang tidak merata sepanjang tahun dimana petani hanya akan mendapatkan pendatan lebih di masa musim panen kopi dan hortikultura yaitu pada bulan April, Mei dan Juli, selebihnya petani hanya menggantungkan pendapatannya pada tanaman hortikultura jangka pendek dan sektor lain diluar pertanian seperti buruh bangunan di kota, berdagang, supir dan lain-lain. Sehingga secara umum masyarakat petani akan nampak miskin akibat ketidakmampuannya dalam memenuhi kebutuhannya. Oleh karena itu, untuk dapat mengelola kebutuhan diperlukan adanya peningkatan sumberdaya petani dalam mengelola pendapatan sehingga mampu merencanakan pemenuhan kebutuhan keluarga dalam satu tahun.
\end{abstract}

Kata kunci : pola nafkah, petani kopi, pendapatan petani

\begin{abstract}
Poverty is synonymous with the farming community, poverty bondage seems to be a disease of society that has been passed down for generations. One factor exacerbating this condition is the lack of resources of the farming community in managing their potential.The purpose of this study was to look at the patterns of living of coffee farmers in a disadvantaged village. The study involved 70 farmer families interviewed. Data analysis uses a quantitative data approach which is then supported by a qualitative approach. The results showed that, the inability of farmers to meet their needs completely was not due to lack of farmer's income but, the inability of farmers to manage finances in order to meet family needs. Unequal farmer income throughout the year where farmers will only get more income in the harvest season of coffee and horticulture, namely in April, May and July, the rest farmers only depend on short-term horticultural crops and other sectors outside agriculture such as construction workers in the city, trading, driver etc. So that in general the farming community will look poor due to their inability to meet their needs. Therefore, to be able to manage the needs, an increase in farmers' resources in managing income is needed so that they are able to plan to fulfill family needs in one year.
\end{abstract}

Keywords: coffee farmers, farmer income, livelihood patterns

\section{PENDAHULUAN}

Sebagian besar negara berkembang dengan berpenghasilan rendah di dominasi oleh masyarakat petani. Kemiskinan sangat identik dengan masyarakat petani, jeratan kemiskinan seolah menjadi penyakit masyarakat yang sudah turun temurun. Salah 
satu faktor yang memperparah kondisi ini adalah kurangnya sumber daya masyarakat petani dalam mengelola potensi yang dimiliki. Kondisi ini menjadi faktor pembatas bagi mereka untuk berfikir membentuk pola nafkah produktif bagi pemenuhan kebutuhan rumah tangga mereka. Pola nafkah petani memiliki peran bukan hanya sebagai strategi untuk mensejahterakan keluarga petani namun secara umum memiliki peran yang signifikan dalam meningkatkan perekonomian daerah.

Mata pencaharian berkelanjutan dipandang sebagai bagian dari konsep untuk mensejahterakan petani telah ramai dibahas. Mata pencaharian didefinisikan di sini sebagai activities kegiatan, aset, dan akses yang secara bersama menentukan kehidupan yang diperoleh oleh individu atau rumah tangga(Ellis, 1999). Konsep pola nafkah hadir memberikan cerminan tentang cara pemenuhan kebutuhan keluarga, salah satunya adalah sistem diversifikasi mata pencaharian (atau diversifikasi pekerjaan atau diversifikasi tenaga kerja yang kita gunakan secara bergantian), adalah salah satu ciri paling menonjol dari mata pencaharian pedesaan.

Mata pencaharaian usahatani kopi yang selama ini diusahakan oleh petani dianggap tidak mampu mensejahterakan masyarakat petani kopi. Produktivitas tanaman kopi yang semakin menurun berdampak pada penurunan pendapatan petani. Kondisi ini mulia dianggap mengkhwatirkan oleh petani sehingga mereka berupaya mulai mencari sumber pendapatan alternatif untuk menunjang kebutuhan finansial keluarga mereka.

Penelitian ini bertujuan untuk mengklasifikasikan pola nafkah keluarga petani kopi serta melihat perbandingan pola nafkah petani kopi selama satu tahun. Selanjutnya menentukan bagaimana peran masing masing pola nafkah yang adopsi petani dalam memenuhi kebutuhan masyarakat petani kopi.

\section{BAHAN DAN METODE}

\section{Lokasi dan Waktu Penelitian}

Lokasi penelitian dilaksanakan di daerah tertinggal di sulawesi selatan tepatnya di Desa Ujungbulu, Kabupaten Jeneponto, kawasan pegunungan dimana lokasi tersebut mempunyai komoditi unggulan kopi dan tanaman hortikultura yang berpotensi untuk dikembangkan. Penelitian ini dilakukan pada bulan Februari sampai Mei 2019.

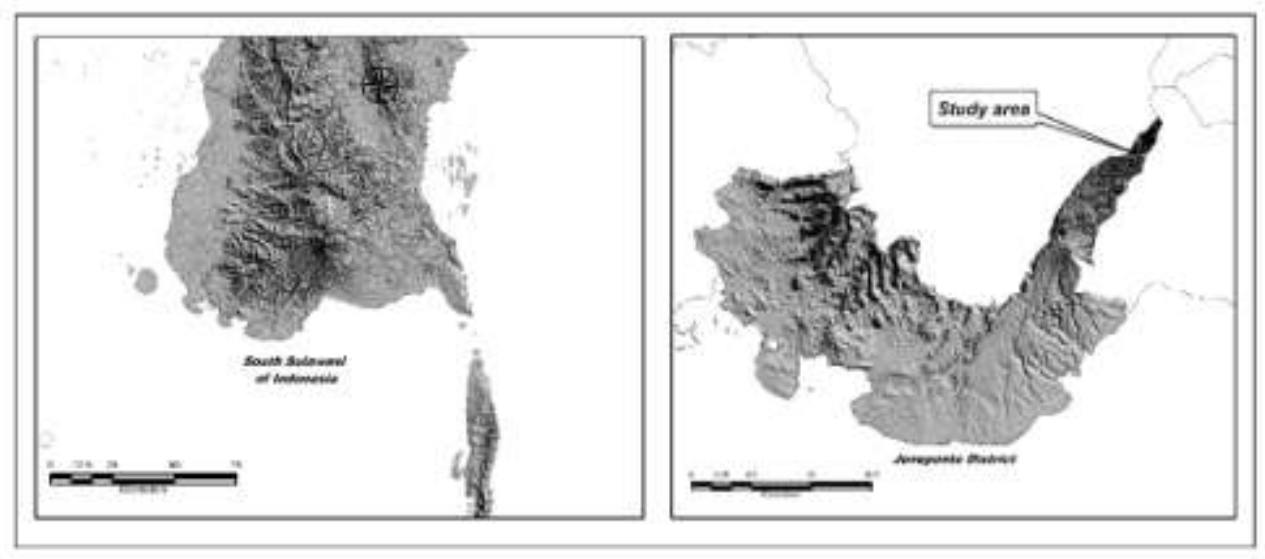

Gambar 1. Lokasi penelitian.

\section{Analisis Data}

Penelitian ini melibatkan 70 responden keluarga petani kopi yang diambil secara acak. Analisis data menggunakan statistik deskriptif dalam bentuk grafik dan tabel distribusi frekuensi.

\section{HASIL DAN PEMBAHASAN}

\section{Pola Nafkah}

Pola nafkah petani berdasarkan hasil penelitian dapat di klasifikasikan sebagai berikut: 
Tabel 1. Klasifikasi pola nafkah keluarga petani kopi.

\begin{tabular}{lcc}
\hline \multicolumn{4}{c}{ Petani yang mampu memenuhi kebutuhan bulanannya } \\
\hline Pola nafkah & Jumlah $(n)$ & Persentase (\%) \\
\hline On Farm & 9 & 12.86 \\
Diversifikasi & 28 & 40.00 \\
\hline & Petani yang tidak mampu memenuhi kebutuhan bulanannya \\
\hline On Farm & 25 & 35.71 \\
Diversifikasi & 8 & 11.43 \\
\hline Total & 70 & 100.00 \\
\hline
\end{tabular}

Pola nafkah keluarga petani kopi dilokasi penelitian dikelompokan menjadi dua yaitu, on farm dengan usahatani komoditas pertanian campuran dan pola diversifikasi yaitu antara usahatani dan usaha lainnya diluar sektor pertanian. Berdasarkan kemampuan untuk memenuhi kebutuhan rumah tangganya ditemukan bahwa, keluarga petani dengan pola nafkah diversifikasi lebih mapan dengan persentase sebesar $40 \%$ jika dibandingkan dengan petani dengan pola nafkah yang mengandalkan usahatani saja yaitu hanya sebesar $12.86 \%$. Sedangkan keluarga petani yang tidak mampu dalam pemenuhan kebutuhan keluarganya diperoleh sebesar $35.71 \%$ berasal dari keluarga petani dengan pola nafkah on farm saja dimana mereka hanya menggantungkan nafkahnya pada usahatani sedangkan petani yang memiliki usaha diversifikasi diluar sektor pertanian memiliki persentase yang lebih rendah yaitu hanya sebesar $11.43 \%$.

\section{Manajemen Pola Nafkah}

Hasil penelitian dapat dilihat pada diagram yang memperlihatkan perbandingan antara pendapatan dan pengeluaran keluarga petani kopi dalam kurun waktu satu tahun.

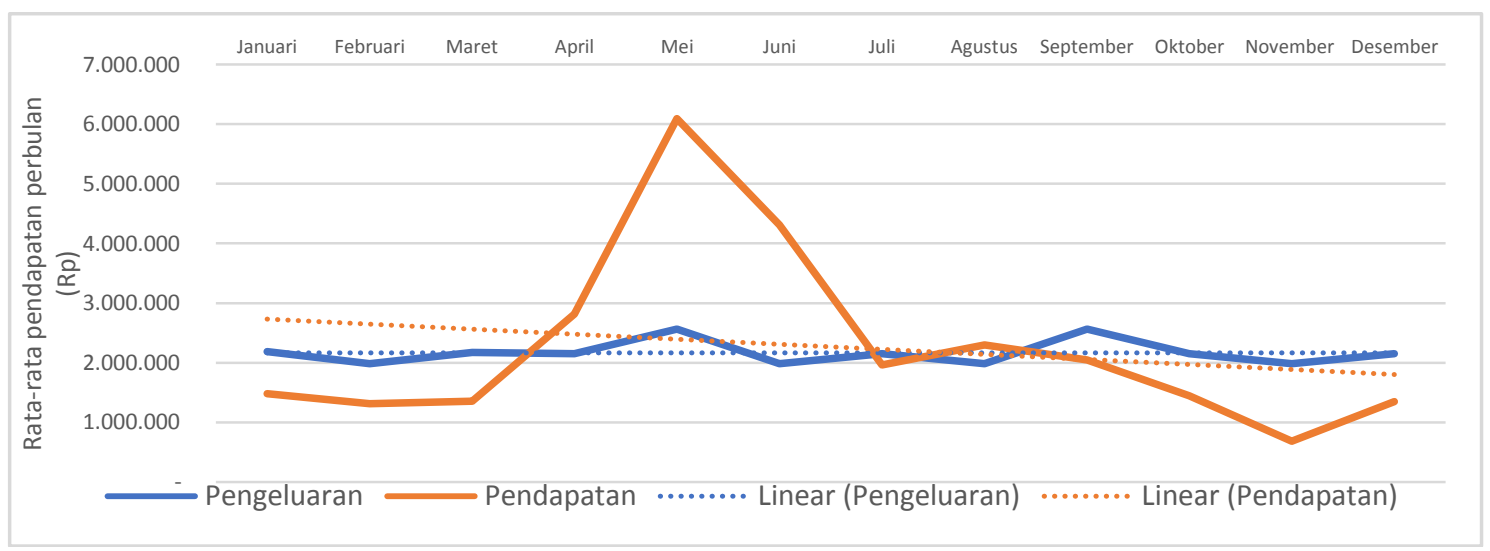

Gambar 2. Perbandingan rata-rata pendapatan dan pengeluaran keluarga petani dalam kurun satu tahun.

Ketidakmampuan petani dalam memenuhi kebutuhan pokoknya bukan karena ketidakmampuan petani secara finansial namun ketidakmampuan petani dalam mengelola pendapatan yang diperoleh sehingga pada bulan bulan tertentu seperti pada bulan Oktober sampai Maret, dimana $47.15 \%$ keluarga petani mengalami kekurangan finansial untuk mencukupi kebutuhan pokok mereka. Dalam kondisi ini jalan lain yang ditempuh keluarga petani adalah melakukan pinjaman finansial apabila keadaan sudah tidak memberikan pilihan lain. Dibeberapa keluarga petani ditemukan, mereka lebih memilih hidup survive dalam kekurangan dari pada harus meminjam uang.

Rata-rata penghasilan tinggi keluarga petani kopi berada pada bulan April, Mei dan 
Juni, dimana pada masa ini musim panen kopi dan beberapa tanaman hortikultura tiba. Puncak tertingginya berada pada bulan Juni dimana pendapatan rata-rata petani pada bulan ini meningkat mencapai Rp.6.097.000,-. Jika dibandingkan antara pendapatan (Rp.2.266.000,-) dan pengeluaran (Rp.2.165.000,-) petani sepanjang tahun, masih diperoleh angka positif, artinya secara finansial mereka masih dapat menutupi semua biaya kebutuhannya. Sumbangsih pendapatan terbesar secara umum berasal dari pola nafkah petani dengan pola diversifikasi.

Kelangsungan hidup pedesaan di banyak negara berpenghasilan rendah, diversifikasi memiliki atribut positif untuk keamanan mata pencaharian yang lebih besar daripada konotasi negatif yang mungkin dimilikinya. Kebijakan harus memfasilitasi bukannya menghambat keragaman. Mata pencaharian pedesaan yang beragam kurang rentan daripada yang tidak terdiversifikasi (Ellis, 2000). Untuk menjawab masalah ini, masyarakat petani perlu merencanakan strategi nafkah sebagai dasar untuk pengambilan keputusan dan pola nafkah yang tepat.

Strategi nafkah merupakan strategi pencarian sumber penghidupan yang bisa ditekuni untuk membiayai segala kebutuhan seluruh anggota keluarga dalam jangka panjang baik di saat miskin maupun di saat sejahtera (dinyatakan sebagai strategi intensifikasi lahan pertanian jika hanya menekuni pertanian dan peternakan, dan diversifikasi strategi nafkah jika menekuni bidang pertanian dan wiraswasta nontani, petani serta migrasi jika melakukan migrasi) (Sugiharto et al., 2016). Ada dua strategi yang bisa dilakukan, diantaranya untuk dapat memenuhi kebutuhan keluarga sepanjang tahun, keluarga petani perlu untuk belajar manajemen pola nafkah, yaitu kegiatan perencanaan melalui pengelolaan keuangan keluarga guna mengantisipasi kebutuhan di masa yang akan datang. Kegiatan ini dilakukan dengan pencatatan kebutuhan keluarga dan alokasi biaya yang akan disiapkan. Selama ini petani tidak pernah melakukan kegiatan perencanaan seperti ini, bahkan hanya untuk melakukan pencatatan keuangan saja mereka enggan melakukannya.
Strategi kedua adalah manajemen pengelolaan sumber pendapatan keluarga. Sumber pendapatan yang baik adalah usaha yang mampu mendatangkan pendapatan sepanjang waktu, misalnya perbulan. Baik untuk satu usaha maupun dilakukan dengan cara diversifikasi usaha. Untuk usahatani bisa dilakukan dengan intensifikasi, mengatur pola tanam beberapa tanaman yang memiliki waktu panen berbeda, misalnya lahan tanaman kopi sebagian dialokasikan untuk tanaman hortikultura yang masa panennya bisa dilakukan tidak bersamaan dengan musim panen kopi. Selain itu juga bisa dilakukan dengan pengaturan waktu tanam, perencanaan waktu tanam sangat penting dilakukan dalam usahatani, selain untuk mengatur sumber pendapatan juga dilakukan untuk menghindari panen massal untuk komoditi tertentu yang dapat menyebabkan jatuhnya harga komoditas, hal ini bisa berdampak pada penurunan pendapatan bahkan sampai kerugian.

Sumber pendapatan alternatif yang diusahakan oleh petani dengan pola on farm adalah usahatani seledri, tanaman hortikultura ini merupakan sumber pendapatan penyangga untuk memenuhi kebutuhan perbulan, rata-rata pendapatan untuk usaha tani ini diperoleh tiap bulannya karena dapat dipanen sepanjang waktu.

Pada penelitian ini ditemukan bahwa ketidakmapanan keluarga petani yang hanya mengandalkan pola nafkah dari usaha onfarm saja bukan berarti mereka harus mencari sumber pendapatan alternatif di sektor lain atau secara instan mengganti komoditas usaha tani di lahan, namun sistem pertanian yang selama ini diterapkan petani masih berskala usahatani, belum menyentuh pada skala bisnis. Sistem pertanian yang diusahakan oleh masyarakat petani selama ini masih dalam skala usaha tani dan belum berkembang menjadi skala bisnis tani yang sifatnya berkelanjutan. Sehingga secara turun temurun meskipun usaha tani mampu menghidupi keluarga petani namun tidak untuk mensejahterahkan petani lebih jauh (Junais, 2019). Kopi adalah tanaman potensial untuk dikembangkan dalam agribisnis, selain komoditas ekspor, permintaan kopi dalam negeri semakin meningkat setiap tahunnya seiring bertumbuhnya usaha kedai dan café di kota kota besar. 
Pendapatan petani dari usahatani kopi mengalami penurunan setiap tahunnya merupakan pertanda tidak produktifnya usahatani ini dikerjakan oleh petani. Banyak petani telah melakoni pola nafkah diversifikasi dengan harapan mampu sejahtera. Pertanyaan kemudian yang muncul apakah pola nafkah dengan sistem diversifikasi mampu mensejahterakan petani? Penelitian yang telah dilakukan oleh Gautam (2016) di sebuah daerah di Nepal menemukan bahwa pola nafkah diversifikasi tidak berkontribusi pada kesejahteraan petani, sistem diversifikasi ke sektor lain belum tentu memungkinkan untuk dapat memanfaatkan peluang ekonomi baru secara efektif bahkan di masa depan. Selanjutnya dinyatakan bahwa kemampuan rumah tangga untuk melakukan diversifikasi ke sektor lain tergantung pada tingkat sumber daya yang dan aset yang dimiliki. Apabila masalah ini tidak dapat di atasi, berpeluang untuk mendatangkan masalah baru yang lebih besar yaitu adanya perubahan perspektif di masyarakat petani yang mengisyaratkan mereka menjadikan peluang usaha diluar sektor pertanian untuk diprioritaskan sehingga secara bertahap mereka meninggalkan usahatani mereka. Disisi lain ketidakmapanan petani mengadopsi usaha diluar sektor pertanian juga sangat rentan terhadap guncangan ekonomi.

\section{KESIMPULAN}

Ketidakmampuan petani dalam memenuhi kebutuhannya sepenuhnya bukan karena kurangnya pendapatan petani, namun ketidakmampuan petani dalam mengelola keuangan dalam rangka memenuhi kebutuhan keluarga. Pendapatan petani yang tidak merata sepanjang tahun dimana petani hanya akan memperoleh pendapatan lebih di masa musim panen kopi dan hortikultura yaitu pada bulan April, Mei dan Juli, selebihnya petani hanya menggantungkan pendapatannya pada tanaman hortikultura jangka pendek dan sektor lain diluar pertanian seperti buruh bangunan di kota, berdagang, supir dan lain-lain. Sehingga secara umum masyarakat petani akan nampak miskin akibat ketidakmampuannya dalam memenuhi kebutuhannya.
Oleh karena itu, untuk dapat mengelola kebutuhan diperlukan adanya peningkatan sumberdaya petani dalam mengelola pendapatan sehingga mampu merencanakan pemenuhan kebutuhan keluarga dalam satu tahun. Apabila masalah ini tidak dapat diatasi, berpeluang untuk mendatangkan masalah baru yang lebih besar yaitu adanya perubahan perspektif dimasyarakat petani yang mengisyaratkan mereka menjadikan peluang usaha diluar sektor pertanian untuk di prioritaskan.

\section{UCAPAN TERIMA KASIH}

Terima kasih kepada Kementerian Riset, Teknologi, dan Pendidikan Tinggi Republik Indonesia yang telah mendanai penelitian ini. Serta kepada Pusat Penelitian dan Pengembangan Sumber Daya Alam Universitas Hasanuddin atas dukungan fasilitasnya selama penelitian ini.

\section{DAFTAR PUSTAKA}

Ellis, F. 2000. The determinants of rural livelihood diversification in developing countries. Journal of Agricultural Economics Vol. 51(2), 289-302.

Ellis, F. 1999. Rural livelihood diversity in developing countries: evidence and policy implications. Overseas Development Institute, London.

Gautam, Y. dan Andersen, P. 2016. Rural livelihood diversification and household well-being: Insights from Humla, Nepal. Journal of Rural Studies Vol. 44: 239-249.

Junais, I. 2019. Persepsi kaum petani muda dan orang tua terhadap masa depan pertanian: integrasi sosio-spasial terhadap petani kopi di Kab. Jeneponto. IOP Conference Series 2019.

Sugiharto, A., Hartoyo dan Muflikhati, I. 2016. Strategi nafkah dan kesejahteraan keluarga pada keluarga petani tadah hujan. Jurnal IImu Keluarga dan Konsumen Vol. 9(1): 33-42. 
Sumarti, T. 2007. Kemiskinan petani dan strategi nafkah ganda rumah tangga pedesaan. Jurnal Sosiologi Pedesaan Vol. 1(2): 217-232. 